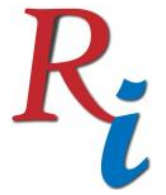

Asia Proceedings of Social Sciences

(APSS)

www.readersinsight.net/APSS

\title{
STUDENTS’ PERCEPTION OF SPOKEN ENGLISH ANXIETY AT HIGHER EDUCATION LEVEL
}

Afsheen Salahuddin

Lahore College for Women University, Lahore

Pakistan

*Corrosponding author's Email: afsheensalahuddin50@gmail.com

Author's Biography

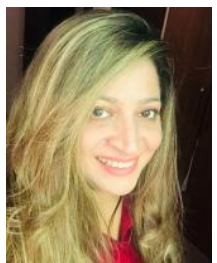

Afsheen Salahuddin is an English language leturer in the Unversity of Central Punjab.Lahore Pakistan. She is persuing her PhD degree in Education with research area in 'English Language Teaching' from Lahore College for Women University.Lahore. Pakistan.

Peer-review under responsibility of $3^{\text {rd }}$ Asia International Multidisciplanry Conference 2019 editorial board (http://www.utm.my/asia/our-team/) (C) 2019 Published by Readers Insight Publisher, lat 306 Savoy Residencia, Block 3 F11/1,44000 Islamabad. Pakistan, info@ readersinsight.net This is an open access article under the CC BY-NC-ND license (http://creativecommons.org/licenses/by-nc-nd/4.0/). 


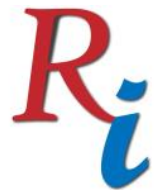

Asia Proceedings of Social Sciences

(APSS)

www.readersinsight.net/APSS

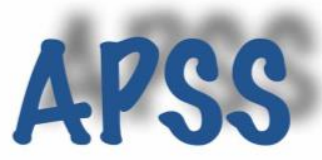

\section{Rese a r ch H i g h I g h t s}

The results of the present study conducted in a private sector university of the Lahore city in Pakistan showed that interactive activities if utilized peoperly help in developing the spoken English skill of the students at higher education level.The utilization of interactive activitiees in English language classrooms are the need of the hour in developing countries like Pakistan.

\section{Research Objectives}

The basic objective of this study was to explore certain factors which make students anxious while they talk in a foreign language i.e. English language. The study aimed to see the effect of the interactive activities on the students' spoken English confidence level from the students' perspective. Another objective of the study was to develop a model of interactive activities for teaching English language, which can be incorporated in the curriculum of the institute. This has also been proved by the review of literarture that interaction helps building up confidence and speeding up the learning process.

Interaction helps develop confidence among people even outside the classroom setting thus making them better at everything they do. (Cunliffe, 1976). It has been discovered that students find interactive activities more motivating and therefore they learn more while participating in them rather than listening to plain boring lectures. (Angelo et.al, 1993).

The model developed in the present study has taken its basis from the Vygotsky's theory of cognitive development. Allwright, 1984 stated that Vygotsky's theory of cognitive development stages states that adults play a crucial role in the cognitive development for younger ones because adults transmit their tools of intellectual adaptation that children internalize and the children follow these eventually setting them as a figure to be like.

In developing countries like Pakistan English language is the second language therefore spoken English anxiety is common in the students as shown in the previous research studies. A research was conducted in the University of Baluchistan in 2017 to assess the anxiety level of students utilizing the same questionnaire which was also filled by the students of the present study i.e. Foreign Language Classroom Anxiety Scale (FLCAS) developed by Elaine Horwitz. The questionnaire selected 18 items from the total 33 questions. Students' responses showed that they feel anxious whenever they try to speak correct English. (Ahmed et al, 2017) Bhatti and Memon have also conducted a research in a few public sector colleges of Hyderabad city in the province Sindh in Pakistan utilizing the same questionnaire but in adapted form. It was a quantitative study which was conducted to investigate the views of English Language Learners on Language learning anxiety. The research was conducted on 145 Intermediate level students. (Bhatti \& Memon 2016) The findings of the present research study are in line with these previous studies as it revealed the presence of anxiety in the foreign language learning students.

\section{Significance of the Study}

In developing countries like Pakistan English language is the second language therefore spoken English anxiety is common in the students as shown in the previous research studies. This study has tried to present the causes and propose some solutions for language anxiety which can be useful to language educators and students. This study is also significant within our context i.e. Pakistani context because in our country so far, no concrete steps have been taken so far to eliminate the spoken English anxiety especially in the public sector institutes. 


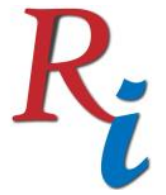

\section{Asia Proceedings of Social Sciences \\ (APSS) \\ www.readersinsight.net/APSS}

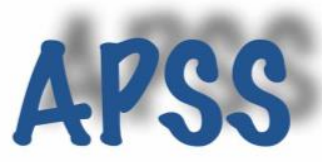

\section{Methodology}

The present study was conducted in the city Lahore, Pakistan and it is a mixed method study. It was a quasi-experimental pre-test post-test study. An intact group of 40 students were divided equally in one control group and two experimental groups. The study has two parts i.e. a quasiexperimental part and the researcher's observations part which were done during the study. The Quasi experimental pre-test, pot-test design was adopted for the study. The students were divided into two groups i.e. one control and one experimental group. All the students were provided with a questionnaire to fill which contained closed ended questions i.e. Foreign Language Classroom Anxiety Scale (FLCAS) developed by Elaine Horzwitz. The students' responses were recorded in the pre-test through this questionnaire. After the data collection from the pre-test, the intervention started. The control group was taught with the routine methodology consisting of basically traditional text books which contain comprehension passages and grammatical exercises. The experimental group was taught using interactive activities like role plays, short informal interviews, and small presentations and so on. There were two sessions per week, each session consisted of one and a half hour, both for the control group and the experimental groups. The intervention lasted for eight months or two semesters.

\section{Results}

The students' responses were calculated through percentages scores and when they were compared in the pre-test and post-test it was found that the students of the control group had not shown any advancement in their spoken English confidence level while the experimental group showed a significant improvement in their confidence level when they talked in English.. The researcher's observations were also recorded for the qualitative analysis .It was observed that the students' behavior including body language, eye contact and gestures showed considerable improvement. The results showed that the interactive activities had enhanced the confidence and reduced anxiety in the students while they speak in a foreign language.

\section{Findings}

It was found out that interactive activities if utilized properly can enhance the confidence level of the students in their spoken English skill.It was found out that the teachers should be trained properly in order to enable the students to be able to speak English fluently. The research also pin-points that the institutes that do not encourage their students to interact in English language often have students who do not have good conversational skills in English. Thus it is proposed that the interactive activities should be incorporated in the English language classrooms.

\section{References}

Ahmed, N., Pathan, Z. H., \& Khan, F. S. (2017). Exploring the Causes of English Language Speaking Anxiety among Postgraduate Students of University of Balochistan, Pakistan. International Journal of English Linguistics, 7(2), 99.

Allwright, R. L. (1984). The importance of interaction in classroom language learning. Applied linguistics, 5(2), 156-171.

Angelo, T., Cross, K. P., Morrison-Shetlar, A., Marwitz, M., Silberman, M., VanGundy, A., \& Watkins, R. (1993). Interactive Techniques.

Bhatti, N., \& Memon, S. (2016). Investigating the Perceptions of Pakistani English Language Learners on Language Learning Anxiety in EFL Classroom. Advances in Language and Literary Studies, 7(5), 23-34.

Cunliffe, S. V. (1976). Interaction. Journal of the Royal Statistical Society. Series A (General), 139(1), 1-19. 